\title{
Variability in chemical and mechanical properties of Pará rubber (Hevea brasiliensis) trees
}

\author{
Jirawat Riyaphan ${ }^{\mathrm{a}}$, Thitaporn Phumichai ${ }^{\mathrm{b}}$, Trairat Neimsuwan ${ }^{\mathrm{c}}$, Suteera Witayakran ${ }^{\mathrm{d}}$, \\ Krissada Sungsing ${ }^{\mathrm{e}}$, Rangsarid Kaveeta ${ }^{\mathrm{a}}$, Chalermpol Phumichai ${ }^{\mathrm{a}, *}$ \\ a Department of Agronomy, Faculty of Agriculture, Kasetsart University, Bangkok 10900 Thailand \\ b Rubber Research Institute of Thailand, Phaholyothin Road, Chatuchak, Bangkok 10900 Thailand \\ c Department of Forest Products, Faculty of Forestry, Kasetsart University, Bangkok 10900 Thailand \\ d Kasetsart Agricultural and Agro-Industrial Product Improvement Institute, Kasetsart University, \\ Bangkok 10900 Thailand \\ e Surat Thani Rubber Research Centre, Canthulee, Thachana, Surat Thani 84170 Thailand
}

*Corresponding author, e-mail: chalermpol.ph@gmail.com, agrcpp@ku.ac.th

Received 3 Jun 2014

Accepted 17 Aug 2015

\begin{abstract}
Pará rubber (Hevea brasiliensis) is grown primarily for latex. Some clones (timber clones) are frequently planted for wood production. Rubberwood, from old rubber trees, is an important economic byproduct. In general, the quality of the wood depends on multiple factors, including chemical and mechanical properties. This study investigates the effects of clone variety, height (1.3 and $6.0 \mathrm{~m}$ above ground level), and the variation between clone and height on chemical and mechanical properties of seven Pará rubber clones (RRIT 251, RRIM 600, RRI-CH-35-59, RRI-CH-35-650, RRI-CH-35-1397, RRI-CH-35-1757, and RRI-CH-35-2086). Thirteen-year old trees were sampled selecting one tree per clone. Results showed that height had a significant effect on the chemical components of the wood. Furthermore, the interaction between clone and height also had an effect on the chemical composition of cellulose, hemicelluloses, lignin, and extractives. In contrast, the mechanical properties of rubberwood depended a lot on the clone variety. The chemical and mechanical properties of rubberwood were significantly correlated among the seven clones studied. RRI-CH-351757, RRI-CH-35-2086, and RRIM 600 had the highest values for holocellulose as the main chemical components and mechanical strength.
\end{abstract}

KEYWORDS: rubberwood, holocellulose, $\alpha$-cellulose, modulus of rupture, modulus of elasticity

\section{INTRODUCTION}

Pará rubber (Hevea brasiliensis) is now widely cultivated in Asia, especially in Southeast Asia ${ }^{1}$, and has recently become an important economic crop in Thailand. Rubber applications include latex and wood production. The latex has been used for vehicle tires, medical appliance, shoes, condoms, and cosmetics. Rubberwood is normally used to manufacture furniture and wood panelling. Recently, medium density fibreboard, particleboard, and oriented-strand board have been produced from rubberwood $^{2}$. Rubberwood is obtained by cutting old rubber trees (25-30 years of age) after the latex production has decreased. After 25 years, rubber trees usually have a clear bole of 3-10 m, depending on the tree and the growing conditions ${ }^{3}$.

Variation in wood properties depends upon specific environmental and genetic factors ${ }^{4}$. For example, wood chemical properties depend upon factors including species, age, height, and their growth environment ${ }^{5}$. The main chemical components of wood are cellulose, hemicelluloses, lignin, and extractives. In general, softwoods from gymnosperms have higher cellulose and lignin, and lower pentosan levels compared to hardwoods or angiosperms ${ }^{6}$. Among many studies regarding wood chemical properties, $\mathrm{Hu}$ et $\mathrm{al}^{7}$ reported that the deposition of lignin and cellulose can be regulated in ways that allow woody perennial plants to grow, yet maintain strength. In addition, Reghu ${ }^{8}$ showed that the lignin percentage of wild Hevea germplasm ranged from $19-25 \%$, whereas that of Wickham clones ranged from $21-23 \%{ }^{8}$. The same group also revealed that lignin biopolymer and cell wall phenolic quantities can be reliable tools for early detection of wood quality and growth in $H$. brasiliensis. Zaki et $\mathrm{al}^{9}$ studied two latex timber clones, Rubber Research Institute of Malaysia (RRIM) 2009 and RRIM 2024, and found significant variation in holocellulose and $\alpha$-cellulose contents between these clones. Moreover, wood at the base 
of these trees had the highest $\alpha$-cellulose values within $1.3 \mathrm{~m}$ from the ground.

The mechanical properties of wood indicate its strength properties and behaviour for specific applications ${ }^{10}$. Rubberwood mechanical values vary depending on tree age and height. For example, the tensile strength of wood from the RRIM 600 clone decreases with age, but wood at bottom of the tree retains greater tensile strength than wood at the top $^{4}$. Furthermore, Naji et $\mathrm{al}^{11}$ reported that the fibre length of wood has a significant effect on its mechanical strength and longitudinal shrinkage.

Chemical composition also influences the woods mechanical properties. Specifically, cellulose microfibrils are thought to be responsible for the tensile strength of wood. The structure of cellulose is advantageous for resisting tensile stress ${ }^{12}$, probably due to covalent bonds in the pyranose ring and glucose units ${ }^{6}$.

The present study therefore determines the chemical and mechanical properties of wood from several rubber clones and evaluate their suitability for various applications. Furthermore, the correlation between chemical and mechanical properties of rubberwood was also examined.

\section{MATERIALS AND METHODS}

Seven clones, one tree from each clone type, were selected for this study. All trees were 13 years old and grew under uniform environmental conditions. The plantation was located at Surat Thani Rubber Research Centre, Thailand. These seven clones included two commercial clones (RRIT 251 and RRIM 600) and five of their progenies from a breeding program in 1992 (RRI-CH-35-59; R59, RRI-CH-35650; R650, RRI-CH-35-1397; R1397, RRI-CH-351757; R1757, and RRI-CH-35-2086; R2086). The samples used for chemical and mechanical property testing were prepared from $1.0 \mathrm{~m}$ long trunk cuttings at two positions, $1.3 \mathrm{~m}$ and $6.0 \mathrm{~m}$ above the ground. Logs from the two positions were then cut into three cross sections; one $20 \mathrm{~cm}$ section was used for chemical analysis and two $40 \mathrm{~cm}$ sections for mechanical property analysis (Fig. 1).

Each $20 \mathrm{~cm}$ section was divided into two blocks per height level for chemical composition analysis. Samples taken from the $1.3 \mathrm{~m}$ and $6.0 \mathrm{~m}$ height level consisted of $X_{1}$ and $X_{2}$, and $X_{3}$ and $X_{4}$ samples, respectively. Wood mechanical properties were tested on each block (Fig. 2). Samples from the $1.3 \mathrm{~m}$ and $6.0 \mathrm{~m}$ height were labelled $\mathrm{A}_{1}, \mathrm{~A}_{2}, \mathrm{~A}_{3}$, $\mathrm{A}_{4}, \mathrm{~B}_{1}, \mathrm{~B}_{2}, \mathrm{~B}_{3}, \mathrm{~B}_{4}$, and $\mathrm{A}_{5}, \mathrm{~A}_{6}, \mathrm{~A}_{7}, \mathrm{~A}_{8}, \mathrm{~B}_{5}, \mathrm{~B}_{6}, \mathrm{~B}_{7}, \mathrm{~B}_{8}$, respectively. Four samples from each height level

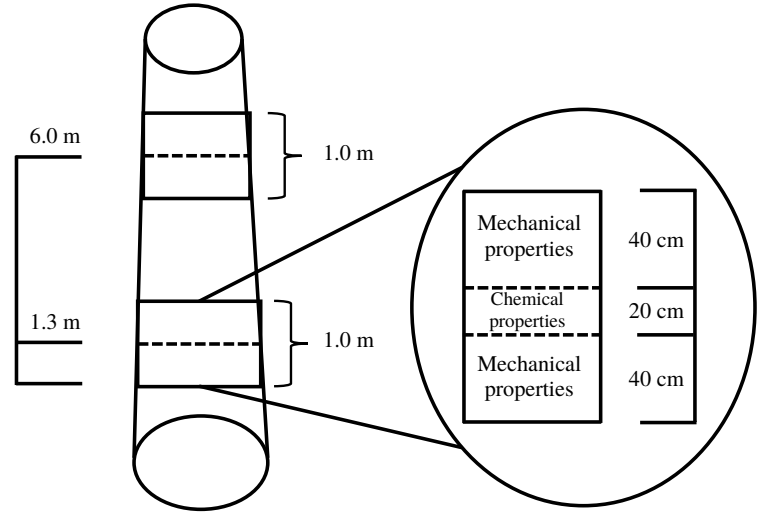

Fig. 1 Diagram showing positions on trunks of Hevea brasiliensis trees from which 1-m logs were harvested, then cut into three sections: one $20 \mathrm{~cm}$ in length for chemical composition analysis, and two $40 \mathrm{~cm}$ in length, above and below, for mechanical properties analysis.

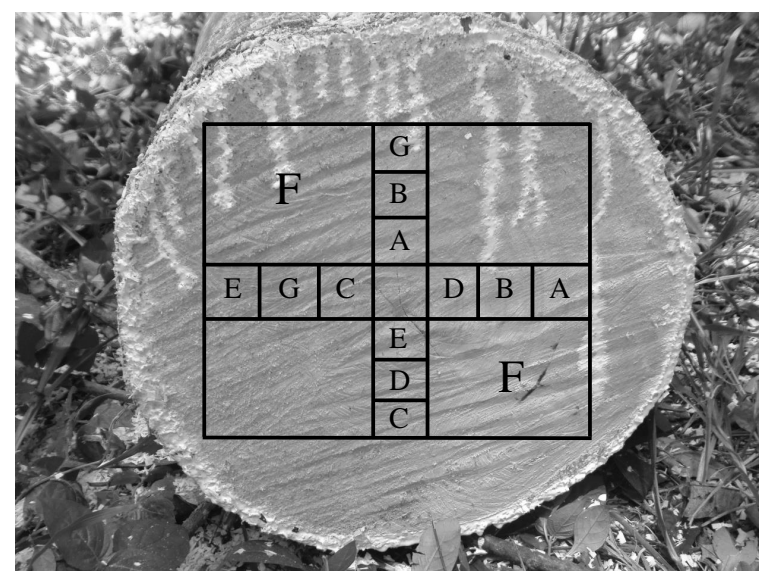

Fig. 2 Diagram showing the distribution of wood samples from a cross-section representative example of two $40 \mathrm{~cm}$ logs for testing mechanical properties (details of mechanical testing are described in Table 1).

for mechanical testing were labelled A and labelled B for chemical composition; therefore, two $40 \mathrm{~cm}$ sections, mechanical properties were measured on eight wood samples (Table 1).

Each tree had four entries per harvest height: $A_{1}, A_{2}, A_{3}, A_{4}(1.3 \mathrm{~m})$ and $A_{5}, A_{6}, A_{7}, A_{8}(6.0 \mathrm{~m})$. Samples for mechanical properties were tested to determine the modulus of rupture (MOR) and the modulus of elasticity (MOE) (sample A), the compression parallel and perpendicular to grain (samples B and D, respectively), the shear parallel to grain (sample C), the tension perpendicular to grain (sample E), the hardness (sample F), and the cleavage (sample G), as shown in Table $1^{13}$. 
Table 1 Details of the mechanical testing of $H$. brasiliensis wood samples.

\begin{tabular}{llcl}
\hline Sample & Property & Dimensions $\left(\mathrm{cm}^{3}\right)$ & Test standard \\
\hline A & MOR \& MOE & $2 \times 2 \times 30$ & $* * *$ \\
B & Compression $\|$ & $2 \times 2 \times 6$ & ISO 3787 \\
C & Shear $\|$ & $2 \times 2 \times 2$ & $* * *$ \\
D & Compression $\perp$ & $2 \times 2 \times 6$ & ISO 3787 \\
E & Tension $\perp$ & $2 \times 2 \times 7$ & ISO 3345 \\
F & Hardness & $5 \times 5 \times 5$ & ISO 3350 \\
G & Cleavage & $2 \times 2 \times 4.5$ & BS. No. 373 \\
\hline
\end{tabular}

$\mathrm{MOR}=$ modulus of rupture; MOE $=$ modulus of elasticity; $\|=$ parallel to grain; $\perp=$ perpendicular to grain; *** = ASTM D143 (Standard Test Methods for Small Clear Specimens of Timber) \& B.S. No. 373; B.S. $=$ British standard.

\section{Chemical composition analysis}

The $20 \mathrm{~cm}$ sections of wood samples were taken from the middle of $1.3 \mathrm{~m}$ and $6.0 \mathrm{~m}$ height. (Fig. 1). The samples were dried outdoors for 2-3 days to decrease moisture content. These samples were then cut into toothpick size pieces and ground into fine particles using a Wiley mill (Brabender, Japan International Cooperation Agency). The ground wood was sieved through 40 mesh $(425 \mu \mathrm{m})$ and $<60$ mesh $(\mu \mathrm{m})$ screen to obtain wood powder.

The wood powder chemical composition was analysed according to the Technical Association of the pulp and Paper Industry (TAPPI) standard methods ${ }^{14}$. Solubility in ethanol-benzene and ethanol was analysed by the TAPPI T $204 \mathrm{~cm}-02$ method (solvent extractives of wood and pulp). Other chemical analysis methods include: TAPPI T 207 om-02 to analyse hot water solubility, TAPPI T 211 om-02 to analyse ash content, TAPPI T 222 om-02 to analyse lignin content, TAPPI T 203 om-02 to analyse $\alpha$-cellulose content, and TAPPI T $223 \mathrm{~cm}-02$ to analyse pentosan content. Holocellulose content was analysed by the acid chlorite method of Browning ${ }^{15}$. Hemicellulose content was calculated as holocellulose- $\alpha$-cellulose ${ }^{16,17}$.

\section{Mechanical property analysis}

The wood mechanical or strength properties included wood consistency (hardness) and the ability to resist applied forces. Samples for mechanical analysis were taken from the $40 \mathrm{~cm}$ sections of the logs. Wood samples from each log were distributed throughout the log cross sections. The specimens were cut and conditioned at $65 \% \mathrm{RH}$ and $20^{\circ} \mathrm{C}$ prior to testing. Data from mechanical tests were recorded into an automatic storage system that reported the relationship between load and deformation, although only the maximum force applied in each test was recorded. Wood density of all samples was determined according to Eckelman ${ }^{18}$, as the dry weight of a sample divided by its volume. The standard for mechanical testing is listed in Table 1.

\section{Statistical analysis}

Differences in rubberwood chemical and mechanical properties at two heights $(1.3 \mathrm{~m}$ and $6.0 \mathrm{~m})$ were evaluated in seven rubberwood clones using a two-stage nested design ${ }^{19}$ including two factors, tree and height level, with height level nested within tree. When a significant effect was detected by ANOVA, Duncan's Multiple Range test was applied to detect the difference among means for chemical and mechanical properties by rubberwood clone and height. These statistical tests were performed using CROPSTAT v. 7.2.3 (http://bbi.irri. org/products). Correlations between chemical and mechanical properties were analysed using Pearson's correlation to identify relationships between traits. The correlation analysis was calculated using PAST palaeontological statistics program, v. $2.17^{20}$ or http://folk.uio.no/ohammer/past/.

\section{RESULTS AND DISCUSSION}

\section{Chemical properties}

Wood samples were analysed to identify the quantity of components in seven rubberwood trees. The ash content at $1.3 \mathrm{~m}$ trunk height was higher than at $6.0 \mathrm{~m}$ (Table 2). At $1.3 \mathrm{~m}$, clones R1397 and R650 had the highest percentage of ash content. Furthermore, clone R650 had the highest ash content at $6.0 \mathrm{~m}$, but greater levels were still found at $1.3 \mathrm{~m}$. The effect of tree on ash content therefore depended on the height of harvested trunk. Generally, the ash content of wood was below $1 \%$, with higher levels in the wood being considered unsuitable for manufacturing paper (TAPPI T211 om-02). Among hardwoods, Eucalyptus camaldulensis and Acacia mangium have ash contents of 0.6 and $0.22 \%$, respectively. Both species would be more suitable raw material for paper and pulp industries due to their low ash content ${ }^{21,22}$. Clone R59 low ash content of $0.6 \%$ may be suitable for manufacturing paper and pulp (Table 2).

Analyses of variance between clone variant and height were significant for ethanol-benzene, ethanol, and hot water solubility (Table 3 ). The ethanol-benzene extracts of rubberwood consisted of non-polar-soluble materials, primarily waxes, fats, resins, gums, and water-soluble substances (TAPPI T204 om-02). The percentage of ethanol- 
Table 2 Chemical composition of wood from seven $H$. brasiliensis clones on $1.3 \mathrm{~m}$ and $6.0 \mathrm{~m}$ heights $(H)$.

\begin{tabular}{|c|c|c|c|c|c|c|c|c|c|c|}
\hline \multirow{2}{*}{$\begin{array}{c}H \\
(\mathrm{~m})\end{array}$} & \multirow[t]{2}{*}{ Clones } & \multicolumn{9}{|c|}{ Chemical composition $(\%)^{\dagger}$} \\
\hline & & Ash & EBS & ES & HWS & $\mathrm{LN}$ & $\mathrm{AC}$ & $\mathrm{HC}$ & HMC & PS \\
\hline \multirow[t]{8}{*}{1.3} & RRIT 251 & $0.8(0.0)$ & $2.8(0.1)$ & $0.5(0.0)$ & $5.6(0.1)$ & $21.2(0.5)$ & $39.4(0.0)$ & $70.6(0.1)$ & $31.1(0.1)$ & $10.5(0.3)$ \\
\hline & RRIM 600 & $1.0(0.0)$ & $2.6(0.1)$ & $0.4(0.0)$ & $6.0(0.1)$ & $21.0(0.0)$ & $39.4(0.1)$ & $70.5(0.2)$ & $31.2(0.1)$ & $12.1(0.7)$ \\
\hline & R59 & $0.7(0.0)$ & $2.9(0.1)$ & $0.8(0.1)$ & $6.2(0.3)$ & $20.3(0.1)$ & $39.8(0.2)$ & $70.7(0.3)$ & $29.8(0.3)$ & $10.6(0.1)$ \\
\hline & R650 & $1.0(0.0)$ & $3.2(0.0)$ & $0.7(0.0)$ & $6.9(0.2)$ & $20.9(0.0)$ & $38.3(0.1)$ & $68.0(0.1)$ & $30.6(0.1)$ & $10.7(0.4)$ \\
\hline & R1397 & $1.1(0.0)$ & $2.9(0.1)$ & $0.4(0.0)$ & $7.4(0.1)$ & $19.0(0.6)$ & $40.1(0.2)$ & $70.7(0.1)$ & $29.7(0.1)$ & $11.9(0.7)$ \\
\hline & R1757 & $0.7(0.1)$ & $2.4(0.1)$ & $0.4(0.0)$ & $6.2(0.6)$ & $19.5(0.6)$ & $41.5(0.4)$ & $71.2(0.7)$ & $29.7(0.0)$ & $10.1(0.6)$ \\
\hline & R2086 & $0.8(0.0)$ & $2.7(0.2)$ & $0.4(0.0)$ & $8.1(0.3)$ & $18.7(0.1)$ & $39.5(0.1)$ & $69.3(0.2)$ & $31.0(0.1)$ & $11.3(0.1)$ \\
\hline & Average & 0.9 & 2.8 & 0.5 & 6.6 & 20.1 & 39.7 & 70.1 & 30.4 & 11 \\
\hline \multirow[t]{11}{*}{6.0} & RRIT 251 & $0.7(0.0)$ & $3.1(0.1)$ & $0.7(0.1)$ & $5.5(0.2)$ & $21.3(0.3)$ & $40.2(0.1)$ & $72.8(0.2)$ & $32.8(0.2)$ & $11.7(0.1)$ \\
\hline & RRIM 600 & $0.7(0.1)$ & $2.8(0.0)$ & $0.6(0.1)$ & $6.4(0.8)$ & $19.8(0.3)$ & $39.7(0.3)$ & $72.5(0.5)$ & $32.7(0.2)$ & $12.8(0.6)$ \\
\hline & R59 & $0.6(0.0)$ & $2.8(0.0)$ & $0.5(0.2)$ & $6.0(0.1)$ & $19.0(0.2)$ & $41.3(0.0)$ & $72.2(0.0)$ & $30.3(0.3)$ & $10.5(0.4)$ \\
\hline & R650 & $1.0(0.1)$ & $3.1(0.1)$ & $0.7(0.0)$ & $6.5(0.1)$ & $20.6(0.1)$ & $39.5(0.0)$ & $69.9(0.0)$ & $32.6(0.2)$ & $12.5(0.5)$ \\
\hline & R1397 & $0.7(0.0)$ & $3.5(0.0)$ & $0.5(0.0)$ & $5.0(0.4)$ & $19.1(0.6)$ & $40.0(0.3)$ & $72.6(0.4)$ & $31.1(0.3)$ & $12.8(0.5)$ \\
\hline & R1757 & $0.8(0.0)$ & $2.3(0.0)$ & $0.4(0.0)$ & $7.0(0.9)$ & $19.7(0.4)$ & $41.5(0.4)$ & $71.8(0.7)$ & $30.3(0.0)$ & $11.2(0.5)$ \\
\hline & R2086 & $0.9(0.0)$ & $2.7(0.0)$ & $0.6(0.0)$ & $6.4(0.3)$ & $18.1(0.5)$ & $42.0(0.3)$ & $73.0(0.5)$ & $30.9(0.0)$ & $10.2(0.5)$ \\
\hline & Average & 0.8 & 2.9 & 0.6 & 6.1 & 19.7 & 40.6 & 72.1 & 31.5 & 11.7 \\
\hline & $5 \%$ LSD & 0.1 & 0.2 & 0.1 & 0.9 & 0.8 & 0.5 & 0.8 & 0.3 & 1 \\
\hline & $F$-test & $* * *$ & $* * *$ & $* * *$ & $* * *$ & * & $* * *$ & $* * *$ & $* * *$ & $* * *$ \\
\hline & CV (\%) & 4.3 & 2.7 & 12 & 6.4 & 1.8 & 0.6 & 0.5 & 0.5 & 4.1 \\
\hline
\end{tabular}

${ }^{\dagger}$ Values in brackets are the S.D.; percentages are based on the oven-dry weight of raw material.

In this Table and next: EBS = ethanol-benzene solubility; ES = ethanol solubility; HWS = hot water solubility; $\mathrm{LN}=$ lignin; $\mathrm{AC}=\alpha$-cellulose; $\mathrm{HC}=$ holocellulose; $\mathrm{HMC}=$ hemicelluloses; PS $=$ pentosan.

$* * *$ Significant at $p<0.001 ; * *$ Significant at $p<0.01 ; *$ Significant at $p<0.05$.

benzene-soluble components was the highest for clone R650 at $1.3 \mathrm{~m}$ and highest for clone R1397 at $6.0 \mathrm{~m}$ (Table 2). The percentages of ethanol and hot-water soluble components were the highest for R59 and R2086 at $1.3 \mathrm{~m}$, respectively. At $6.0 \mathrm{~m}$, clone RRIT 251 had the highest percentage of ethanol-soluble components, and clone R1757 had the highest percentage of hot-water soluble components (Table 2). These rubber trees could be divided into two groups according to the total extract contents. In the first group, tree from clones R650, R59, and R2086 had the highest percentage of all soluble components measured at the $1.3 \mathrm{~m}$ trunk height. In the second group, R1397, RRIT
251, and R1757 had the highest percentages of all soluble components measured at $6.0 \mathrm{~m}$ trunk height (Table 2).

Klason lignin was obtained after removing polysaccharides from extracted wood using $72 \%$ $\mathrm{H}_{2} \mathrm{SO}_{4}{ }^{23}$. Lignin functions in the cohesion of wood and contributes to the mechanical strength ${ }^{24,25}$. At the $1.3 \mathrm{~m}$, lignin content was lower than at $6.0 \mathrm{~m}$ (Table 2). The tree variant and height for lignin content had significant variation (Table 3 ). Reghu ${ }^{8}$ showed that the lignin percent ranged from 19$25 \%$ in wild Hevea germplasm, and from $21-23 \%$ in Wickham trees. Lignin content can be a reliable tool for early determination of genetically variable

Table 3 Results of nested ANOVA for the variation in tree and height on chemical composition of wood from seven rubberwood (H. brasiliensis) trees.

\begin{tabular}{lcccccccccc}
\hline Source & $d f$ & Ash & EBS & ES & HWS & LN & AC & HC & HMC & PS \\
\hline Trees & 6 & 0.04 & 0.37 & 0.05 & 1.12 & 50.66 & 6.15 & 2.63 & 3.61 & 3.23 \\
Trees (height) & 7 & 0.04 & 0.07 & 0.02 & 1.43 & 60.93 & 6.15 & 4.16 & 0.85 & 1.47 \\
Residual & 14 & 0.00 & 0.01 & 0.00 & 0.16 & 0.34 & 0.02 & 0.02 & 0.01 & 0.27 \\
$F$ value (trees) & & 1.20 & 5.68 & 1.88 & 0.79 & 0.83 & 1.00 & 0.63 & 4.21 & 2.19 \\
Pr $>F$ (trees) & & 0.40 & 0.02 & 0.21 & 0.60 & 0.58 & 0.49 & 0.70 & 0.04 & 0.16 \\
$F$ value trees (height) & & 32.52 & 11.44 & 5.59 & 8.55 & 178.70 & 251.35 & 178.93 & 137.17 & 5.34 \\
Pr $>F$ trees (height) & & 0.000 & 0.000 & 0.003 & 0.000 & 0.000 & 0.000 & 0.000 & 0.000 & 0.004 \\
\hline
\end{tabular}


wood quality in $H$. brasiliensis and its concentration increases as samples are taken from higher tree heights ${ }^{26}$.

$\alpha$-Cellulose is the wood pulp fraction resistant to 17.5 and $9.45 \% \mathrm{NaOH}$ solutions under test conditions. In general, the $\alpha$-cellulose value indicates an undegraded, higher-molecular-weight cellulose content in pulp (TAPPI T203 cm-02). Importantly, $\alpha$-cellulose contributes to wood strength, and increases resistance to crushing. Thus a higher $\alpha$-cellulose content results in stronger wood ${ }^{6,27,28}$. At $1.3 \mathrm{~m}$, clone R1757 had the highest $\alpha$-cellulose content (Table 2). ANOVA between tree and trunk height was significant for $\alpha$-cellulose content (Table 3). Clones R1757 and R2086 had the highest $\alpha$-cellulose content at $6.0 \mathrm{~m}$ trunk height (Table 2), consistent with Zaki et al ${ }^{9}$ who reported a significant tree and trunk height interaction for the $\alpha$-cellulose content of rubberwood trees. $\alpha$-Cellulose decreases with increasing tree height because cellulose and hemicellulose form the thicker secondary walls of mature cells at the base of the tree.

Holocellulose comprise the total cellulose and hemicellulose content of a woody material. To determine hollocellulose, all lignin should be removed, leaving the carbohydrates in place ${ }^{29}$. At $1.3 \mathrm{~m}$ trunk height, clone R1757 had the highest holocellulose content (Table 2). However, at $6.0 \mathrm{~m}$ trunk height, tree R2086 had the highest holocellulose content (Table 2). Results in Table 3 showed that the ANOVA between tree and height was significant.

The RRIT 251 clone had the highest hemicellulose content at $1.3 \mathrm{~m}$ trunk height (Table 2), while RRIM 600 had the highest hemicellulose content at $6.0 \mathrm{~m}$ (Table 2). The hemicellulose content in these trees depended on the tree and sample height. Thus the hemicellulose content of rubberwood trees in this study is based on tree height, and height nested within tree, such that hemicellulose content varied at height and among tree clone. Pentosan content contributes to the strength of paper and pulp (TAPPI T223 cm-01) ${ }^{14}$. High pentosan content is desirable because it acts as glue, coordinating the physical linking of other chemical components in wood (TAPPI T223 cm-02) ${ }^{14}$. Differences in pentosan content depend on tree species, age, height, and environmental conditions. The pentosan content of hardwoods ranges from $19-25 \%{ }^{30}$. The RRIM 600 clone had the highest pentosan content at $1.3 \mathrm{~m}$, while clone R1397 had the highest content at $6.0 \mathrm{~m}$ (Table 2). Kocaefe et $\mathrm{al}^{31}$ showed that white birch and quaking aspen (hardwoods) contain 23 and $19 \%$ pentosan, respectively. These results are inconsistent with the decreased pentosan content associated with increased height observed in the present study.

\section{Mechanical properties}

Rubberwood has been categorized as a mediumstrength and naturally durable wood ${ }^{32}$. Density can have an enormous impact on mechanical properties, and can accurately predict mechanical strength values $^{33,34}$. The present study indicated that rubberwood density was not significantly different among the seven trees. Static bending tests, including MOR and MOE, indicated that rubberwood can be a useful material for building construction due to the strength properties. The MOR and MOE values are used to characterize the strength of beams, joists, rafters, and purlins ${ }^{15}$. The results of mechanical properties showed that these seven trees were significantly different $(p=0.000)$ for tensile stress perpendicular to grain (Table 4$)$. The density was significantly different $(p=0.03)$ (Table 4$)$. However, the MOE, compressive stress parallel and perpendicular to the grain, shearing stress parallel to the grain, hardness, and cleavage were not significantly different.

Higher values for MOR and MOE indicate a greater strength and stiffness ${ }^{35}$, respectively. The

Table 4 Results of nested ANOVA for the variation in tree and height on mechanical properties of wood from seven rubberwood (H. brasiliensis) trees.

\begin{tabular}{lcccccc}
\hline Source & $d f$ & Density & MOR & MOE & Tension $\perp$ & Hardness \\
\hline Trees & 6 & 0.00 & 360.01 & 3400000 & 1.88 & 2100000 \\
Trees (height) & 21 & 0.00 & 121.69 & 1500000 & 0.12 & 1100000 \\
Residual & 28 & 0.00 & 117.02 & 1100000 & 0.30 & 234170 \\
$F$ value (trees) & & 2.80 & 2.96 & 2.17 & 15.13 & 1.91 \\
Pr $>F$ (trees) & & 0.03 & 0.30 & 0.08 & 0.000 & 0.12 \\
$F$ value trees (height) & & 0.96 & 1.04 & 1.38 & 0.41 & 4.72 \\
Pr $>F$ trees (height) & 0.53 & 0.45 & 0.21 & 0.97 & 0.00 \\
\hline
\end{tabular}

In this Table and next: MOR: modulus of rupture; MOE: modulus of elasticity; $\perp=$ perpendicular to grain. 
Table 5 Effect of seven rubberwood tree clones on mechanical strength properties.

\begin{tabular}{lccccc}
\hline Clones & Density $\left(\mathrm{g} / \mathrm{cm}^{3}\right)$ & MOR $(\mathrm{MPa})$ & MOE $(\mathrm{MPa})$ & Tension $\perp(\mathrm{MPa})$ & Hardness $(\mathrm{N})$ \\
\hline RRIT 251 & $0.60(0.40)^{\mathrm{a}}$ & $100(12)^{\mathrm{a}}$ & $9400(1200)$ & $1.6(0.4)^{\mathrm{a}}$ & $6500(900)^{\mathrm{a}}$ \\
RRIM 600 & $0.59(0.10)^{\mathrm{a}}$ & $108(9)^{\mathrm{a}}$ & $10400(800)$ & $0.4(0.4)^{\mathrm{b}}$ & $6800(800)^{\mathrm{a}}$ \\
R59 & $0.60(0.10)^{\mathrm{a}}$ & $103(6)^{\mathrm{a}}$ & $10500(1000)$ & $1.4(0.4)^{\mathrm{b}}$ & $5500(700)^{\mathrm{b}}$ \\
R650 & $0.55(0.10)^{\mathrm{b}}$ & $91(21)^{\mathrm{ab}}$ & $8800(1300)$ & $1.4(0.8)^{\mathrm{a}}$ & $5600(500)^{\mathrm{b}}$ \\
R1397 & $0.57(0.10)^{\mathrm{ab}}$ & $101(8)^{\mathrm{a}}$ & $9700(1500)$ & $1.9(0.4)^{\mathrm{a}}$ & $5600(600)^{\mathrm{b}}$ \\
R1757 & $0.58(0.10)^{\mathrm{ab}}$ & $111(7)^{\mathrm{a}}$ & $10400(1200)$ & $1.6(0.4)^{\mathrm{a}}$ & $5800(800)^{\mathrm{ab}}$ \\
R2086 & $0.59(0.10)^{\mathrm{a}}$ & $109(4)^{\mathrm{a}}$ & $10300(900)$ & $1.8(0.3)^{\mathrm{a}}$ & $6200(1000)^{\mathrm{ab}}$ \\
Average & 0.6 & 103 & 9900 & 1.4 & 6000 \\
5\% LSD & 0.03 & 11.47 & 1302.74 & 0.37 & 1093.54 \\
F-test & $*$ & $*$ & NS & $* * *$ & 38.1 \\
CV (\%) & 12.1 & 10.5 & 10.7 & NS \\
\hline
\end{tabular}

Values in brackets are the S.D. Values followed by different letters in each column differed significantly $(p>0.05)$ in Duncan's new multiple range test; *** significant at $p<0.001$; $*$ at $p<0.05$; NS = not significant.

MOR can be used to divide these seven trees into two groups: one group consisting of RRIT 251, RRIM 600, R59, R1397, R1757, and R2086, and the other group consisting of tree R650. The first group had high values for strength in terms of the MOR (Table 5). Bur-flower tree has values of 58 and $5500 \mathrm{MPa}$ for the MOR and MOE, respectively ${ }^{36}$. In comparison, the seven trees in the present study had higher values for strength and stiffness properties in static bending. It is possible that the response to static bending may depend on the test procedure and tree.

Tests of the tensile strength of wood perpendicular to its grain are used to determine the suitability of wood for mechanically connected timber joints ${ }^{13}$. These seven trees can be divided into two groups based on tensile strength perpendicular to the grain: the first group consists of RRIT 251, R650, R1397, R1757, and R2086, and the second group includes RRIM 600 and R59 (Table 5). The first group was performed in the present study and the results indicated they would be suitable for manufacturing furniture due to higher tensile strength than the typical range used in the furniture industry ${ }^{37}$. Moreover, the first group had the highest tensile strength perpendicular to grain.

Hardness is used to determine the suitability of wood for floors, sporting goods, and furniture ${ }^{13}$. These seven trees can be divided into three groups based on the hardness. The first group includes RRIT 251 and RRIM 600, which are commercial trees, the second group R59, R650, and R1397, and the third group R1757 and R2086 (Table 5). The first group had the highest hardness values. Thus RRIT 251 and RRIM 600 would be recommended for planting because both are established commercial trees and can be used for manufacturing furniture.

\section{Correlation between chemical and mechanical properties}

Hemicellulose, lignin, and pentosan contents were negatively correlated with resistance to cleavage properties and tensile strength (Fig. 3). The $\alpha$-cellulose and lignin contents were negatively correlated $(p<0.01)$. Among mechanical properties, the correlation between MOR and MOE was significant ( $p<0.01$, data not shown). In addition, correlation coefficients were significant $(p<0.05)$ between $\alpha$-cellulose and static bending (MOR and MOE), $\alpha$-cellulose and cleavage, lignin and tensile strength perpendicular to the grain, and between pentosan content, and tensile strength perpendicular to the grain (Fig. 3). However, mechanical properties such as hemicellulose content, cleavage, and wood density, and other chemical components of wood were not significantly correlated $(p>0.05)$, even though they play important roles in independently determining wood strength ${ }^{38}$.

Mechanical properties of wood have shown moderate positive correlations with other important wood characteristics ${ }^{39,40}$. This investigation of the relationship between chemical and mechanical properties has provided valuable information. Generally, correlations between MOR and MOE were positive and moderate. One focus of this study was to determine whether $\alpha$-cellulose content and static bending strength parameters were correlated, as both traits theoretically indicate the strength properties of wood. When wood contained higher percentages of $\alpha$-cellulose, the amount of force necessary to achieve maximum load increased. Moreover, $\alpha$-cellulose was also negatively correlated with 

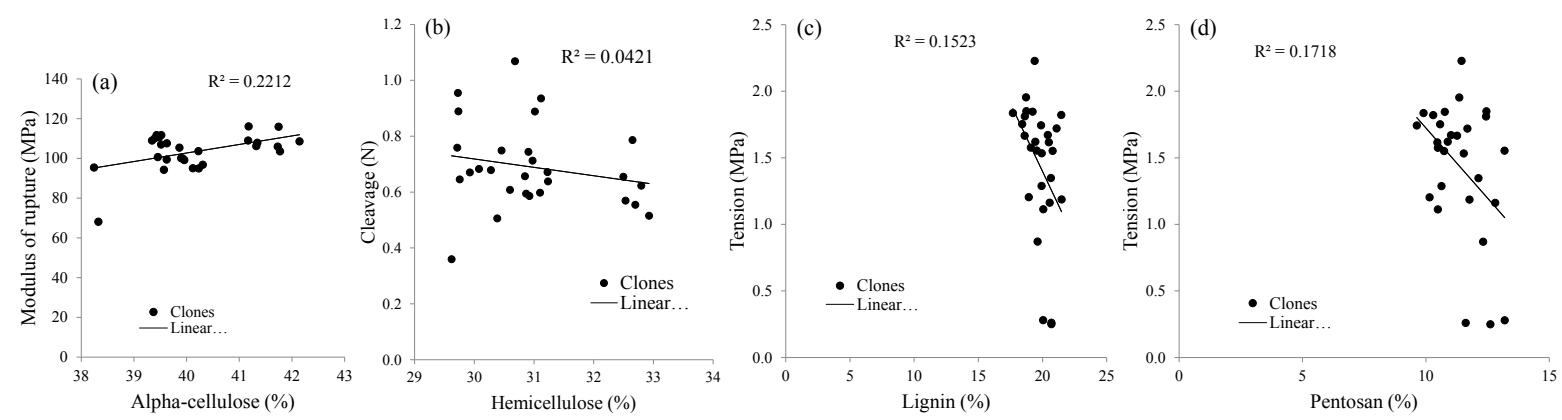

Fig. 3 Relationship between chemical and mechanical properties for important wood traits in $H$. brasiliensis: (a) correlation coefficient between $\alpha$-cellulose content and static bending; (b) correlation coefficient between hemicellulose and cleavage; (c) correlation coefficient between lignin and tension; (d) correlation coefficient between pentosan and tension.

lignin content. Apparently, lignin contributes to only supplementary strength, as do hemicelluloses ${ }^{7}$. There is a strong relationship between the mannan content of $\alpha$-cellulose isolated from wood and the MOR (equivalent to work-to-maximum load) of solid wood ${ }^{40}$. Higher $\alpha$-cellulose content resulted in greater resistance to static bending (MOR and MOE) ${ }^{6,31,41}$. Finally, there were moderate negative correlations between holocellulose and cleavage, and between lignin or pentosan and tensile strength (Fig. 3). However, for the seven rubberwood trees analysed here, there was no relationship between hemicellulose and MOR or MOE.

\section{Conclusion}

The study of chemical and mechanical properties of seven rubberwood trees will provide useful information for breeding programs and provide scientific based evidence for selecting the best tree variety for quality timber and other products. This information can be used for comparative studies with other rubberwood trees being evaluated for wood quality improvement and other applications. All the wood properties that were studied showed a significant difference between clone and height. The effect of height depended on the genetic influence of each tree. Variation in chemical compositions among these rubberwood trees result from the effects between height and tree variety, but the mechanical strength properties resulted only from the effects of trees. Chemical and mechanical properties of wood can predict timber quality, reduce production costs, and increase agricultural and economic benefits derived from the timber. In this study, tree clones R1757, R2086, and RRIM 600 had the best values for chemical composition and mechanical strength that produce high quality wood. These trees have therefore good potential to be used in the rubberwood industry. In the future, three of these seven rubberwood trees will be introduced as latex or timber trees.

Acknowledgements: The authors wish to thank Surat Thani Rubber Research Centre, Thailand for the research materials, and experimental fields.

\section{REFERENCES}

1. Balsiger J, Bahdon J, Whiteman A (2000) The Utilization, Processing and Demand for Rubberwood as a Source of Wood Supply, Forestry Policy and Planning Division, Rome Regional Office for Asia and the Pacific, Bangkok, Thailand.

2. Rubber Research Institute of Thailand (2010) Para Rubber Academic Information, Agricultural Co., Ltd, Bangkok.

3. Lim SC, Gan KS, Choo KT (2003) The Characteristics, Properties and Uses of Plantation TimbersRubberwood and Acacia mangium. Timber Technology Bulletin No. 26, Timber Technology Centre, Kuala Lumpur, pp 1-11.

4. Zobel BJ, Jett JB (1995) Genetics of Wood Production, Springer-Verlag, Berlin, Heidelberg, Germany.

5. Smook GA (1992) Handbook for Pulp and Paper Technologists, 2nd edn, Angus Wilde Publication, Inc., Canada.

6. Rowell RM (2005) Handbook of Wood Chemistry and Wood Composites, Taylor and Francis, New York.

7. Hu W-J, Harding SA, Lung J, Popko JL, Ralph J, Stokke DD, Tsai C-J, Chiang VL (1999) Repression of lignin biosynthesis promotes cellulose accumulation and growth in transgenic trees. Nat Biotechnol 17, 808-12.

8. Reghu CP (2011) Analysis of wood in Hevea brasiliensis: estimation and quantification of lignin bio-polymer and cell wall phenolics. In: IRRDB, International Rubber Conference 15-16 December 2011, Rubber Research Institute, Thailand, pp 1-7.

9. Zaki JA, Muhammed S, Shafie A, Daud WRW (2012) 
Chemical properties of juvenile latex timber clone rubberwood trees. Malays J Anal Sci 16, 228-34.

10. Kretschmann DE (2010) Mechanical properties of wood. In: Wood Handbook-Wood as an Engineering Material, General Technical Report FPL-GTR-190, US Department of Agriculture, Forest Service, Forest Products Laboratory, Madison, WI, pp 5-1-5-44.

11. Naji HR, Sahri MH, Nobuchi T, Bakar ES (2012) Clonal and planting density effects on some properties of rubber wood (Hevea brasiliensis Muell. Arg.). BioResources 7, 189-202.

12. Genet M, Stokes A, Salin F, Mickovski SB, Fourcaud T, Dumail J-F, van Beek R (2005) The influence of cellulose content on tensile strength in tree roots. Plant Soil 278, 1-9.

13. Kyokong B, Doungpet M (1999) Laboratory Manual for Mechanical Testing of Wood, Department of Forest Product, Kasetsart Univ, Bangkok.

14. The Technical Association of the Pulp Paper Industry (2002) TAPPI Standards, TAPPI Press, Atlanta, GA.

15. Browning BL (1967) Methods of Wood Chemistry, Interscience Publishers, New York, London.

16. McMillin CW (1968) Chemical composition of loblolly pine wood as related to specific gravity, growth rate, and distance from pith. Wood Sci Tech 2, 233-40.

17. Ververis C, Georghiou K, Danielidis D, Hatzinikolaou DG, Santas P, Santas R, Corleti V (2007) Cellulose, hemicelluloses, lignin and ash content of some organic materials and their suitability for use as paper pulp supplements. Bioresour Tech 98, 296-301.

18. Eckelman CA (1996) Furniture Manufacturing: Wood Moisture Calculations, Purdue Univ, Forestry \& Natural Resources, West Lafayette, FNR-156.

19. Montgomery DC (1976) Design and Analyses of Experiments, Wiley, Inc., New York.

20. Hammer $\varnothing$, Harper DAT, Ryan PD (2001) PAST: Paleontological statistics software package for education and data analysis. Palaeontolog Electron 4, Art. 4.1.4A.

21. Neimsuwan T, Laemsak N (2010) Anatomical and mechanical properties of the bur-flower tree (Anthocephalus chinensis). Kasetsart J (Nat Sci) 44, 353-63.

22. Pinto PC, Evtuguin DV, Neto CP (2005) Chemical composition and structural features of the macromolecular components of plantation Acacia mangium wood. J Agr Food Chem 53, 7856-62.

23. Sjostrom E (1981) Wood Chemistry, Academic Press, Inc., London.

24. Gierlinger N, Jacques D, Schwanninger M, Wimmer R, Pâques LE (2004) Heartwood extractives and lignin content of different larch species (Larix sp.) and relationships to brown-rot decay-resistance. Trees 18, 230-6.

25. Piquemal J, Lapierre C, Myton K, O'Connel A, Schuch W, Grima-Pettenati J, Boudet AM (1998) Down-regulation of Cinnamoyl-CoA reductase induces signifi- cant changes of lignin profiles in transgenic tobacco plants. Plant $J$ 13, 71-83.

26. Santos RB, Capanema EA, Balakshin MY, Chang H-M, Jameel H (2011) Effect of hardwoods characteristics on kraft pulping process: emphasis on lignin structure. BioResources 6, 3623-37.

27. Wise LE, Jahn EC (1952) Wood Chemistry, The Institute of Paper Chemistry, Appleton, WI.

28. Sixta H (2006) Handbook of Pulp, Wiley-VCH Verlag GmbH \& Co. KGaA, Weinheim, Germany.

29. Wang Q, Chen Q, Apaer P, Kashiwagi N, Kurokawa H, Sugiyama K, Wang X, Guo X (2010) Liquefaction processes and characterization of liquefied products from waste woody materials in different acidic catalysts. In: Brebbia CA (ed) The Sustainable World, WIT Transactions on Ecology and the Environment No. 142, pp 343-54.

30. Fengel D, Wegener G (2003) Wood: Chemistry, Ultrastructure, Reactions, Walter de Gruyter Publishers, Berlin.

31. Kocaefe D, Poncsak S, Boluk Y (2008) Effect of thermal treatment on the chemical composition and mechanical properties of birch and aspen. BioResources 3, 517-37.

32. Royal Forest Department of Thailand (2005) The Thai Hardwoods, Agricultural Co., Ltd, Bangkok.

33. Hacke UG, Sperry JS, Pockman WT, Davis SD, McCulloh KA (2001) Trends in wood density and structure are linked to prevention of xylem implosion by negative pressure. Oecologia 126, 457-61.

34. Larjavaara M, Muller-Landau HC (2010) Rethinking the value of high wood density. Funct Ecol 24, 701-5.

35. Desch HE, Dinwoodie JM (1981) Timber: Its Structure, Properties, and Utilization. Timber Press, Forest Grove, OR.

36. Neimsuwan T, Laemsak N (2010) Chemical properties of bur-flower tree Anthocephalus chinensis (Lam.) A. Rich. ex Walp. Thai $J$ Forest 29, 64-72, [in Thai].

37. Thai Furniture Industries Association (2000) The green label stipulation for products made from rubberwood. Thai Furniture J 43, 32-7, [in Thai].

38. Sweet MS, Winandy JE (1999) Influence of degree of polymerization of cellulose and hemicelluloses on strength loss in fire-retardant-treated Southern pine. Holzforschung 53, 311-7.

39. Nocetti M, Brunetti M, Ducci F, Romagnoil M, Santi F (2010) Variability of wood properties in two wild cherry clonal trials. Wood Sci Tech 44, 621-37.

40. Nocetti M, Brunetti M, Ducci F, Romagnoli M, Rozenberg P, Santi F (2012) Phenotypic correlations among wood properties and growth in wild cherry plantations. BioResources 7, 3160-74.

41. Windeisen E, Bachle H, Zimmer B, Wegener G (2009) Relations between chemical changes and mechanical properties of thermally treated wood. Holzforschung 63, 773-8. 